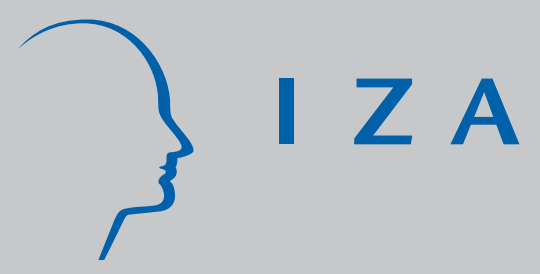

IZA DP No. 2964

The Advantage of Experienced Start-Up Founders in Venture Capital Acquisition:

Evidence from Serial Entrepreneurs

J unfu Zhang

July 2007 


\title{
The Advantage of Experienced Start-Up Founders in Venture Capital Acquisition: Evidence from Serial Entrepreneurs
}

\author{
Junfu Zhang \\ Clark University and IZA \\ Discussion Paper No. 2964 \\ July 2007 \\ IZA \\ P.O. Box 7240 \\ 53072 Bonn \\ Germany \\ Phone: +49-228-3894-0 \\ Fax: +49-228-3894-180 \\ E-mail: iza@iza.org
}

\begin{abstract}
Any opinions expressed here are those of the author(s) and not those of the institute. Research disseminated by IZA may include views on policy, but the institute itself takes no institutional policy positions.
\end{abstract}

The Institute for the Study of Labor (IZA) in Bonn is a local and virtual international research center and a place of communication between science, politics and business. IZA is an independent nonprofit company supported by Deutsche Post World Net. The center is associated with the University of Bonn and offers a stimulating research environment through its research networks, research support, and visitors and doctoral programs. IZA engages in (i) original and internationally competitive research in all fields of labor economics, (ii) development of policy concepts, and (iii) dissemination of research results and concepts to the interested public.

IZA Discussion Papers often represent preliminary work and are circulated to encourage discussion. Citation of such a paper should account for its provisional character. A revised version may be available directly from the author. 


\section{ABSTRACT \\ The Advantage of Experienced Start-Up Founders in Venture Capital Acquisition: Evidence from Serial Entrepreneurs ${ }^{*}$}

Existing literature suggests that entrepreneurs with prior firm-founding experience have more skills and social connections than novice entrepreneurs. Such skills and social connections could give experienced founders some advantage in the process of raising venture capital. This paper uses a large database of venture-backed companies and their founders to examine experienced founders' access to venture capital. Compared to novice entrepreneurs, entrepreneurs with venture-backed founding experience tend to raise more venture capital at an early round of financing and tend to complete the early round much more quickly. In contrast, experienced founders whose earlier firms were not venture-backed do not show a similar advantage over novice entrepreneurs, suggesting the importance of connections with venture capitalists in the early stage of venture capital financing. However, when the analysis also takes into account later rounds of financing, all entrepreneurs with prior founding experience appear to raise more venture capital. This implies that skills acquired from any previous founding experience can make an entrepreneur perform better and in turn attract more venture capital.

JEL Classification: M13, G24

Keywords: firm-founding experience, serial entrepreneur, venture capital

Corresponding author:

Junfu Zhang

Department of Economics

Clark University

950 Main Street

Worcester, MA 01610

USA

E-mail: juzhang@clarku.edu

\footnotetext{
* This paper has benefited from comments and suggestions by Kannika Damrongplasit, Amy Ickowitz, Chris Jepsen, Ting Lu, David Neumark, Xue Song, Brandon Wall, and seminar participants at the Public Policy Institute of California, the $80^{\text {th }}$ Western Economic Association Annual Conference in San Francisco, CA, the $17^{\text {th }}$ Academy of Entrepreneurial Finance Annual Conference in Pasadena, CA, and the 2007 Econometric Society Summer Meetings in Durham, NC.
} 


\section{Introduction}

How does prior firm-founding experience help an entrepreneur to raise venture capital (VC) for a start-up? In this paper, I postulate that earlier founding experience gives an entrepreneur some advantage in terms of the timing of early-stage VC funding and the size of VC deals. I present some supportive evidence based on a comprehensive VC data set. The findings should help scholars as well as practitioners better understand the value of prior founding experience and the VC investment decision process.

To build a firm, a start-up founder has to assemble a group of people with various expertise, gain access to capital and other resources, and act as a manager to implement a business plan. A person who can do this job effectively needs to have a wide range of skills. As Lazear (2004, 2005) has observed, an entrepreneur has to be a "generalist," a “jack of all trades.” An entrepreneur may be born with a general set of skills which he may then supplement by investing in human capital such as formal schooling. ${ }^{1}$ He can also augment the set of skills through "learning by doing” in the process of building a firm, which is particularly important given that some entrepreneurial skills are subtle, uncodifiable, and difficult to teach in classroom. Because of the importance of "learning by doing," experienced start-up founders are expected to have a more complete set of skills and therefore perform better in their subsequent ventures.

In addition, a firm-founding experience also gives an entrepreneur a chance to know or work with a wide range of people, including capitalists (such as bankers, venture capitalists, and “angel” investors), professionals (such as accountants, consultants, lawyers, and human resource specialists), and suppliers or customers. Connections with these people established in previous founding experience increase the entrepreneur's stock of social capital. Some of these connections, even if they are only weak or indirect ties, may become useful in the future when the entrepreneur starts another business.

Because entrepreneurs with prior firm-founding experience tend to have more human and social capital, they may have an edge over first-time entrepreneurs in the process of resource acquisition. To test the validity of this presumption, one needs to focus on entrepreneurs and their firms at a fairly early stage because as firms grow larger

\footnotetext{
${ }^{1}$ For convenience of exposition, I will refer to a firm's founder in singular, male terms throughout the paper, although it is common to have multiple founders for a single firm and there are many female entrepreneurs.
} 
their performance may become less and less determined by their founders. In this paper, I examine start-ups and their founders in the context of VC acquisition. I compare experienced start-up founders, which I will refer to as serial entrepreneurs, with first-time founders, which I will refer to as novice entrepreneurs. Using a sample of entrepreneurs who have gained access to VC, I investigate whether serial entrepreneurs show any advantage over novice entrepreneurs. ${ }^{2}$ I will distinguish between VC- and non-VCbacked prior founding experience and examine whether they both help an entrepreneur in the process of raising $\mathrm{VC}$ for subsequent firms.

VC acquisition provides an ideal situation in which an entrepreneur's prior founding experience can be found to make a difference. VC investment is characterized by an asymmetric information problem between equity investors and the entrepreneur (Leland and Pyle, 1977; Amit et al., 1990; Fried and Hisrich, 1994; Gompers, 1995). VC investors often bet millions of dollars on a start-up, whose future success will in large part be determined by the quality of the founder. Usually investors possess less information about the entrepreneur's ability and the viability of his business plan than the entrepreneur himself does. This information asymmetry prevents venture capitalists from investing a large amount of money in start-ups.

There are many ways to overcome this asymmetric information problem (Gompers and Lerner, 1999). In a sense, the general practice of staged investment in the VC industry is meant to provide a partial solution to this problem (Gompers, 1995). Venture capitalists almost always make investment decisions stage by stage: they only provide a small amount of money to a start-up initially, and base later investment decisions on the start-up's performance. In this way, venture capitalists can evaluate the entrepreneur's ability and the viability of his plan over time. Furthermore, as another solution to the asymmetric information problem, venture capitalists rely heavily on the referrals of social contacts to identify and evaluate an entrepreneur (Tyebjee and Bruno, 1984). Venture capitalists naturally favor entrepreneurs that have either direct or indirect social connections with them (Shane and Cable, 2002). Mutual social connections not only bridge information transfer between investors and the entrepreneur, but may also

\footnotetext{
${ }^{2}$ It is quite possible that serial entrepreneurs are more likely to get VC funding than novice entrepreneurs. But that is not the focus of this study.
} 
serve as an informal monitoring group. For example, if the entrepreneur does anything unprofessional that adversely affects the venture capitalists' financial returns, he would have to consider the possibility of losing the trust of many other people in the same social network. Therefore, these mutual social connections could greatly bolster VC investors' confidence in the entrepreneur.

Because of these features of the VC investment process, there are reasons to believe that experienced start-up founders have advantages over novice founders. First, the staged investment implies that the experienced founder, if he indeed acquired entrepreneurial skills from prior founding experience, would have opportunities to reveal such skills over time and raise more VC in later rounds after investors see his better performance. Second, prior experience may have helped the entrepreneur establish connections to venture capitalists that facilitate his access to VC. Novice entrepreneurs, on the contrary, may not have such connections to rely on.

The remainder of the paper is organized as follows. Section 2 reviews related literature based on which some testable hypotheses are formulated. Section 3 describes the database used in this study and presents some descriptive statistics. Section 4 presents empirical results. Section 5 concludes with some remarks on this paper's contributions, limitations, and directions for future research.

\section{Theoretical Background and Hypotheses}

This study is built on two strands of literature. The first concerns the value of entrepreneurial experience and the second is about venture capitalists' investment decisions. In this section, I review the related literature to develop testable hypotheses.

\subsection{Entrepreneurial experience and experienced entrepreneurs}

MacMillan (1986) calls for intensive study of "habitual entrepreneurs" who have the experience of generating multiple businesses. He argues that habitual entrepreneurs have had "the opportunity to learn how to efficiently and swiftly overcome the stumbling blocks they encountered in their first efforts.” Thus they have accumulated entrepreneurial skills from their experiences. By studying these entrepreneurs, researchers will be able to uncover and codify their skills and techniques and gain a deeper understanding of the process of business creation. This view is echoed by other 
authors (see, e.g., Donkels et al., 1987; Starr and Bygrave, 1991; Scott and Rosa, 1996; Rosa, 1998; Carter and Ram, 2003).

Despite the long-recognized value of studying serial entrepreneurs, empirical research in this area is still at the beginning stage (Wright et al., 1998), perhaps due to a lack of suitable data. The bulk of existing research is descriptive, using various sources of data to detect statistically significant differences between novice and experienced entrepreneurs. Chambers et al. (1988) examine the performance of 100 new firms in southeastern Michigan and find that the founding team's previous founding experience does not help, although previous managerial experience has a positive effect. Kolvereid and Bullvag (1993) compare 250 novice and experienced Norwegian entrepreneurs. They find experienced entrepreneurs are more resourceful, tend to get involved in a more competitive business environment, but show no difference in terms of performance. Using data from Great Britain (in some cases, Scotland only), Westhead, Wright, and coauthors compare novice entrepreneurs with multiple-firm founders along many dimensions such as demographic characteristics, background and motivations, skills and knowledge, attitudes to entrepreneurship, organizational capabilities, primary industry activity, geographic location, and business performance (Birley and Westhead, 1994; Westhead and Wright, 1998a, 1998b; Westhead et al., 2005a, 2005b, 2005c; Wright et al. 1997a, 1997b). ${ }^{3}$ Similar comparisons have also been made based on data from other countries. Carland et al. (2000) use survey data on U.S. entrepreneurs to study demographic and psychological differences between single and multiple business owners (operators), and Schaper et al. (2005) examine the differences between the two groups in personal and business characteristics using Australian data. As a result of this recent literature, a lot has been learned about the characteristics of serial entrepreneurs. However, because many of the existing studies are univariate analyses (statistically testing the difference of the means), overall there is still very limited understanding of how prior founding experience helps an entrepreneur subsequently.

\footnotetext{
${ }^{3}$ Some of these studies (Westhead and Wright 1998a, 1998b; Westhead et al., 2005a, 2005b, 2005c; Wright et al. 1997a, 1997b) make a distinction between "serial” and "portfolio" entrepreneurs, with the former referring to those who founded multiple firms in a sequential manner and the latter to those who start multiple firms at the same time. In this paper, I do not distinguish between them and will call all of them serial entrepreneurs.
} 
The primary motivation behind this line of work is the belief that prior founding experience enhances a firm founder's entrepreneurial skills, which in turn will help the entrepreneur's subsequent firms in various contexts. Following the tradition in this literature, in this paper I will maintain the assumption that prior founding experience helps enhance entrepreneurial skills that may lead to better firm performance. In addition, I will make a key observation that prior founding experience also helps establish social connections, increasing the entrepreneur's stock of social capital.

The importance of the entrepreneur's social capital in the process of founding a firm is widely researched. ${ }^{4}$ This line of research generally takes some forms of the entrepreneur's social capital as given and studies their effects on the performance of the firm. In a study of entrepreneurs in St. Joseph County, Indiana, Birley (1985) reports that informal contacts of family, friends, and colleagues are an entrepreneur's primary sources of help in the process of assembling resources to build the firm. Uzzi (1999) shows that firms with connections to banks are more likely to get loans and tend to pay lower interest. Using survey data on 202 seed-stage VC investors, Shane and Cable (2002) find that direct and indirect ties between entrepreneurs and the investors affect the selection of ventures to finance. Using data from China, Batjargal and Liu (2004) find that strong ties between entrepreneurs and venture capitalists have significant effects on contractual covenants, investment delivery, and venture valuation.

In this study, I accept the importance of the entrepreneur's social connections in the process of resource acquisition. More specifically, I assume that an entrepreneur's ties to VC investors should facilitate his access to VC funding. Unlike most of the existing studies that identify social connections using survey data, I instead use venture-backed prior founding experience as a proxy for established ties to the VC world. It is a common practice that several venture capitalists form a syndication to fund a start-up together (Bygrave and Timmons, 1992; Gompers and Lerner, 1999; Sorenson and Stuart, 2001). To monitor a start-up and provide professional advice to its management team, some of the VC investors will sit on the start-up's board of director and work closely with the founding team (Bygrave and Timmons, 1992; Gompers and Lerner, 1999; Hellmann,

\footnotetext{
${ }^{4}$ See, e.g., Batjargal and Liu (2004); Birley (1985); Cooke and Wills (1999); Davidsson and Honig (2003); Florin et al. (2003); Fried and Hisrich (1994); Elfring and Hulsink (2003); Hansen (1995); Jenssen (2001); Jenssen and Koenig (2002); Shane and Cable (2002); Uzzi (1999), and Yli-Renko et al. (2001).
} 
2000). In this process, a VC-backed entrepreneur will become familiar with a group of venture capitalists. He will get to know an even larger group of professionals who have a working relationship with these VC investors. I assume that these connections to the VC world would help a serial entrepreneur in later ventures.

Two existing studies focus on serial entrepreneurs in the context of VC investment. Wright et al. (1997a) surveyed 55 venture capitalists in Great Britain to study their perspectives on investing in serial entrepreneurs who have exited from their previous ventures. They find that venture capitalists indeed make extensive use of serial entrepreneurs, especially in management buy-ins. Hsu (2007) examines 149 early stage start-up firms and finds that an entrepreneur's previous firm-founding experience increases both the likelihood of receiving VC investment through a direct tie and the valuation of the start-up by venture capitalists. However, no one has studied the performance of serial entrepreneurs in terms of the timing of the VC fund and the amount of VC raised, which will be the focus of this paper.

\subsection{Venture capitalists' investment decision process}

There exists a considerable amount of literature on how venture capitalists select start-ups to fund. ${ }^{5}$ Research along this line has relied heavily on data obtained through personal or telephone interviews and mail surveys. Shepherd and Zarcharakis (1999) review this literature and discuss its methodological limitations. They observe that the most consistent finding across studies is the importance that venture capitalists placed on the ability of the founding team, whether it is their managerial capabilities (Tyebjee and Bruno, 1981, 1984), track record (Hutt and Thomas, 1985), staying power and familiarity with the market (MacMillan et al., 1987), or their general traits (Hisrich and Jankowitz, 1990). Naturally, venture capitalists tend to fund entrepreneurs that appear to have more skills.

Although the existing literature has focused primarily on which entrepreneurs get VC funding and which get declined, it is important to recognize that the VC investment process involves a series of decisions. Venture capitalists not only have to choose which entrepreneurs/start-ups to fund, they also need to decide how quickly to make the initial

\footnotetext{
${ }^{5}$ See, e.g., Bruno and Tyebjee (1983, 1986); Franke et al. (2007); Hisrich and Jankowitz (1990); Hutt and Thomas (1985); MacMillan et al. (1985, 1987); Muzyka et al. (1996); Riquelme and Rickards (1992); Sandberg et al. (1988); Tyebjee and Bruno (1981, 1984).
} 
investment, how to stage the later rounds of investment, and how much to invest in each round. I hypothesize that in all these later decisions, the quality of the entrepreneur still matters.

At the center of this series of VC investment decisions is an information asymmetry problem between the entrepreneur and investors (Leland and Pyle, 1977; Amit et al., 1990; Fried and Hisrich, 1994; Gompers, 1995; Shane and Cable, 2002). That is, although venture capitalists want to base their decisions on the quality of the entrepreneur and use all possible channels to gather relevant information during the screening process, it is never possible to know as much about the entrepreneur as the person himself does. For example, venture capitalists usually do not know for sure how competent the entrepreneur is as a manager; they are unlikely to fully understand the technology on which the entrepreneur is building the start-up; they have no way to verify the entrepreneur's evaluation of market opportunities; and they cannot predict how much effort the entrepreneur will put into building the start-up. This information asymmetry problem not only affects who the investors will fund, but also determines how quickly they will invest and how much they will invest.

As Shane and Cable (2002) observed, there are two types of solutions to the information asymmetry problem. The economics/finance literature emphasizes the staging of capital and the risk-sharing feature of the design of VC investment contracts as a solution (Gompers, 1999; Gompers and Lerner, 2000; Kaplan and Strömberg, 2001, 2003, and 2004). For example, venture capitalists usually delay the entrepreneur's compensation until some information about performance becomes available. They distribute their investment over different stages and make later stage investment contingent on outcomes. They also reserve the right to terminate the investment in case a certain performance target is not reached. Given these common practices by venture capitalists, suppose entrepreneurs indeed learn from previous experiences (Ucbasaran et al., 2003), they will likely raise more VC. This is because their acquired skills will make their start-ups perform better and thus attract more VC investment (MacMillan et al., 1985; Riquelme and Rickards, 1992). However, the staged VC investment process implies that acquired skills tend to attract more VC in later stages, when investors have had enough time to observe the experienced entrepreneur's performance. 
The second way to overcome the information asymmetry problem is the social embeddedness solution (Shane and Cable, 2002). This line of research is inspired by the social embeddedness theory proposed by Granovetter (1985) and is generally pursued by organizational scholars in the economic sociology literature. The main idea is that economic decisions such as VC investment are not made in an isolated economic context. Rather, they are embedded in a social environment. In particular, personal relationship could affect which entrepreneurs get funded, how quickly they get funded, and how much VC money they can raise in each deal. In situations of uncertainty and asymmetric information, people with both direct and indirect ties to investors could gain an advantage (Burt, 1997; Podolny, 1994; Uzzi, 1996).

Direct ties between the entrepreneur and investors provide chances for them to meet in other settings. Such interactions tend to develop mutual trust between them. They also allow investors to see the quality of the entrepreneur before they make an investment decision. Indirect ties could transfer information about the entrepreneur to investors which is often more trusted than information revealed through more formal channels. An indirect tie, such as a common friend of the entrepreneur and an investor, may serve as a referral for the entrepreneur. In addition, linkage to the same social network gives the investors more confidence in the entrepreneur because social sanctions help prevent the entrepreneur from engaging in opportunistic behaviors that will hurt the investors. Shane and Cable (2002) show that ties to venture capitalists indeed increase the chance of getting funded.

Again, given the staging of VC investment, if social ties to venture capitalists play a role, its importance should be most prominent in an early round of financing. Once an entrepreneur raises some VC and begins to work with the investors, the investors will have time to observe and interact with the entrepreneur. Thus, over time, the disadvantage associated with the lack of social ties to venture capitalists should diminish. This last prediction was not investigated by Shane and Cable (2002) but will be studied in this paper.

\subsection{Testable hypothesis}

I distinguish between two types of serial entrepreneurs, one group with venturebacked prior firm-founding experience and the other group with non-venture-backed 
founding experience. Venture-backed founding experience is assumed to have helped entrepreneurs to establish ties to the cycle of venture capitalists. They not only know venture capitalists (thus have direct ties) but also know professionals working closely with venture capitalists (thus have indirect ties). These ties will help entrepreneurs in the process of VC acquisition. But as discussed above, they help in the very early stage. Nonventure-backed founding experience, in contrast, does not establish ties to venture capitalists and does not help in the very early stage of VC financing.

Hypothesis 1a: Entrepreneurs with venture-backed prior founding experience have quicker access to VC.

Hypothesis 1b: Entrepreneurs with non-venture-backed prior founding experience do not have quicker access to VC.

Hypothesis 2a: Entrepreneurs with venture-backed prior founding experience raise more $\mathrm{VC}$ in an early round of VC financing.

Hypothesis 2b: Entrepreneurs with non-venture-backed prior founding experience do not raise more VC in an early round of VC financing.

Both types of serial entrepreneurs should have acquired some skills from prior founding experience, which should help their firms perform better and in turn attract more VC. As discussed above, this advantage should appear only if one follows the entrepreneurs beyond the early stage of $\mathrm{VC}$ financing. Therefore, if the analysis covers the whole process of VC acquisition, including both early and later rounds of VC financing, it is expected that entrepreneurs with both venture-backed and non-venturebacked experience will raise more VC.

Hypothesis 3a: Entrepreneurs with venture-backed prior founding experience raise more VC over the whole process of VC financing.

Hypothesis 3b: Entrepreneurs with non-venture-backed prior founding experience raise more VC over the whole process of VC financing.

To test these hypotheses, I use the VentureOne database.

\section{Data}

\subsection{Data source}


The data used in this study were provided by VentureOne, a leading VC research company based in San Francisco. ${ }^{6}$ Founded in 1987, VentureOne tracks equity investment by regularly surveying VC firms for recent funding activities and portfolio updates, gathering information through contacts at venture-backed companies, and scouring various secondary resources such as company press releases and initial public offering (IPO) prospectuses (VentureOne, 2001). VentureOne tries to capture all the venture-backed companies in the United States and their early-stage financing events. ${ }^{7}$

VentureOne claims to have "the most comprehensive database on venture-backed companies. ${ }^{8}$ For each VC deal, VentureOne keeps a record of its size, stage of financing, closing date, $\mathrm{VC}$ firms involved, and detailed information about the firm that received the investment, including its address, start year, industry, and so on. In addition, VentureOne keeps track of the venture-backed company by monthly contacts with the company and its investors. VentureOne continuously updates the information about the venture-backed company's employment size, business status, and ownership status until the VC support is brought to an end by certain events such as a bankruptcy of the venture-backed company, an IPO, or a merger and acquisition (M\&A) that allows venture capitalists to cash out. Although VentureOne's database is maintained for commercial purposes, its rich information has attracted many academic researchers. ${ }^{9}$ Comparing VC databases with actual VC financing contracts, Kaplan et al. (2002) find that the VentureOne data are generally more reliable, more complete, and less biased than the Venture Economics data, the only other major source of VC data.

The particular version of the data used here covers VC deals completed from the first quarter of 1992 through the fourth quarter of 2001. It includes 22,479 rounds of equity investment in 11,029 venture-backed companies. Among these firms, $83.5 \%$ were

\footnotetext{
${ }^{6}$ VentureOne, previously owned by Alternative Investor, was acquired by Dow Jones \& Company in 2004. Thus it is now often referred to as "Dow Jones VentureOne."

${ }^{7}$ A firm enters the VentureOne database only if it qualifies as a "venture-backed company" that receives some investment from venture capital firms. VentureOne defines a venture capital firm as "a professional, institutional venture capital limited partnership that generally manages over \$20 million in assets and invests in privately held companies" (VentureOne, 2000). Once in the database, VentureOne tracks the company's financing from all sources, including bank loans and IPO. In this study, I focus on VC funding only. I not only exclude bank loans and IPOs, but also drop equity investment by non-VC private investors and corporations in order to have a homogeneous sample.

${ }^{8}$ See http://www.ventureone.com/ (accessed on April 23, 2006).

${ }^{9}$ For recent empirical work using the VentureOne data, see, for example, Gompers and Lerner (2000), Cochrane (2005), Gompers et al. (2005, 2006), and Zhang (2006, 2007).
} 
founded in or after 1990. See Zhang (2007) for a more detailed description of the database.

VentureOne also provided a separate data set containing information about venture-backed firm founders. The founder data are incomplete: Founder information is available for 5,972 of the 11,029 venture-backed firms. ${ }^{10}$ Since many firms are cofounded by more than one individual, the data set gives a total of 10,530 individual founders. For each of these founders, there is a data field containing brief biographical information of the person. It describes the founder's previous working experience, which, in most cases, specifies the position he held as well as the companies or institutions where he worked. Every firm has a unique identification number, which appears in both the firm data and the founder data and makes it possible to match a firm with its founder (when the founder information is available).

It is worth noting that due to VentureOne's database management practice the availability of founder information seems unlikely to be entirely random. A start-up enters VentureOne's database once it receives equity investment from a VC firm. VentureOne regularly updates the information about the venture-backed firm until it ceases operation, is acquired by another firm, or goes public. Therefore, VentureOne will follow some firms longer than others. VentureOne naturally has more chances to obtain a firm's founder information if the firm has been followed longer. Indeed, I find that firms with founder information tend to be privately held, and are less likely to be out of business, acquired by other firms, or complete an IPO. Younger firms also tend to have founder information available. ${ }^{11}$ In the subsequent analysis, I will focus exclusively on firms with founder information. Thus one has to keep this non-random selection of sample in mind when interpreting the results. ${ }^{12}$

\footnotetext{
${ }^{10}$ Some founder information is available for 6,629 firms. But in some cases, the most crucial biographical information of the founder is missing, which cuts down the usable sample to 5,972 firms.

${ }^{11}$ Probably because a start-up founded in later years of the sample period tends to have a company website that usually reveals a lot of information about the founding team.

${ }^{12}$ Gompers et al. $(2005,2006)$ also use the VentureOne data and rely on the founder information to identify "spinoff firms" (in the case of Gompers et al., 2005) and "serial entreprenurs" (in the case of Gompers et al., 2006). In both papers, they supplement the original VentureOne founder data by searching the missing information through sources such as Lexis-Nexis and surviving companies' websites. Just like the practice of VentureOne, the added founder information by Gompers et al. could also introduce some bias because the information of successful founders should be found more easily. They noted this problem in both papers. But their search of alternative sources does give them a more complete sample. Unfortunately, I
} 


\subsection{Identification and characterization of serial entrepreneurs}

To test the hypotheses formulated in section 2, the first step is to identify all the serial entrepreneurs in the VentureOne data. For convenience of exposition, I make a distinction between repeat entrepreneurs and experienced entrepreneurs in the empirical definition of serial entrepreneurs. A founder is defined as a repeat entrepreneur if he is matched with two or more firms in the VentureOne data. A total of 304 founders qualify as repeat entrepreneurs. Among them, 264 entrepreneurs have two firms each in the VentureOne data, 26 have three firms each, 11 have four firms each, and three have five firms each. Because founding date is available for every firm, the sequence of founding activities is known for every repeat entrepreneur.

If a founder has only one firm in the VentureOne data, that does not mean he has no previous firm-founding experience. The biographical information of the remaining founders reveals that additional 2,563 entrepreneurs have been firm founders previously. I will call this group of 2,563 individuals experienced entrepreneurs. Both repeat and experienced entrepreneurs are serial entrepreneurs, and there are 2,867 of them in total. All other 7,663 entrepreneurs will be referred to as novice entrepreneurs. This classification of entrepreneur types is summarized in Table 1.

Novice entrepreneurs apparently have no prior founding experience. They will serve as the reference group for comparison in the regression analysis. Experienced entrepreneurs are identified as serial entrepreneurs only by their biographical information. That is, their previous firms are not captured by the VentureOne data. It is most likely that their previous firms never received any VC and therefore VentureOne did not track them. In my analysis below, I will treat experienced entrepreneurs as if they only have non-venture-backed prior founding experience. ${ }^{13}$ Repeat entrepreneurs, when they founded their second and later firms in the sample, apparently had venture-backed

cannot do the same because VentureOne, citing the concern of confidentiality, replaced real company and founder names with identification numbers in my version of the data.

${ }^{13}$ This must be true for a great majority of the experienced entrepreneurs because VC was generally unavailable to most firm founders, especially prior to 1995. One cannot rule out the possibility that their previous firms did receive some VC but the deals were all completed before VentureOne started to track venture-backed firms and thus not captured by the database. Yet this possibility has to be very small given that the sample shows that only a small fraction of venture-backed entrepreneurs have two or more venturebacked firms. 
prior founding experience. However, it is reasonable to assume that when they founded their first firms in the sample they had no venture-backed prior founding experience.

To characterize repeat and experienced entrepreneurs, I have two options in choosing the unit of analysis: an entrepreneur or a firm founded by the entrepreneur. In some cases, one choice is clearly more sensible than the other. For example, a repeat entrepreneur has founded multiple firms, which may be located in different states and belong to different industries. In that case, it makes more sense to examine the geographic or industry distribution of firms founded by repeat entrepreneurs instead of the entrepreneurs themselves. On the other hand, a firm may have multiple founders, some of whom may be serial entrepreneurs and others may not be. Thus if I use the firm as the unit of analysis, it is necessary to make clear what it means to say "a firm founded by a serial entrepreneur.”

In this paper, I always choose whichever unit of analysis is more sensible for the empirical question at hand. When I analyze the firms, I will always assign a firm to its most experienced founder in cases where there are multiple founders. That is, I consider a firm as founded by a serial entrepreneur if only one of its founders has previous founding experience. The underlying assumption for this practice is that a start-up's access to VC is determined by the most experienced entrepreneur on its founding team. This assumption, although arbitrary, seems to be the most reasonable way to treat firms with multiple founders given that no other information about the founding team is available. ${ }^{14}$

Tables 2 and 3 present the industry and geographic distributions of venturebacked firms by entrepreneur type. Compared with novice entrepreneurs, repeat entrepreneurs are more likely to have venture-backed firms in biopharmaceutical, telecommunication, and medical device industries (Table 2). Notice that these are all highly knowledge-intensive industries, and venture-backed firms in these industries are often built around very complex and advanced technologies that investors are unlikely to grasp. It is possible that because of this feature of such industries, venture capitalists tend to favor entrepreneurs with a track record of VC financing. It is even possible that venture capitalists invest in the same entrepreneurs who they supported before in those

\footnotetext{
${ }^{14}$ This is a conservative assumption in that if access to VC is not determined by the most experienced founder, the advantage of the experienced founder will be underestimated, against finding supportive evidence for hypotheses 1-3.
} 
industries (although this information is not available in my version of the VentureOne data). Firms founded by experienced entrepreneurs and novice entrepreneurs have more similar industry distributions, except that experienced entrepreneurs have a significantly larger presence in the consumer/business services industry.

Table 3 shows that repeat entrepreneurs are more likely to have firms in California and Massachusetts. These two states have the most successful high-technology centers (Silicon Valley and Route 128) in the U.S., which must have provided a large base of venture-backed entrepreneurs who could potentially become repeat entrepreneurs. The concentration in California is particularly striking: while $44 \%$ of all venture-backed firms are located in California, 58\% of those founded by repeat entrepreneurs are in California. In contrast, firms founded by experienced entrepreneurs are not so much more concentrated in California and Massachusetts than those founded by novice entrepreneurs.

From this version of the VentureOne data, it is impossible to know exactly whether repeat entrepreneurs indeed go back to the venture capitalists who previously supported them to seek investment for their subsequent start-ups. ${ }^{15}$ But one can observe whether a repeat entrepreneur moves far away from the previous firm when he starts the next one. Given that VC investment and other supporting services (such as those provided by accountants, investment bankers, lawyers, and consultants) tend to have a local focus, ${ }^{16}$ entrepreneurs who moved far away are less likely to take advantage of their already established ties to VC investors.

For each pair of consecutive firms founded by the same repeat entrepreneur, I first find the longitude/latitude coordinates of their zip codes, and then use the surfacedistance formula to calculate the distance between them. ${ }^{17}$ Figure 1 shows the distribution of the distance between two consecutive firms founded by a repeat

\footnotetext{
${ }^{15}$ VentureOne has this information, but I do not have access to it.

${ }^{16}$ See, e.g., Gompers and Lerner (1999), Sorenson and Stuart (2001), and Zook (2005) for the local preference of VC investors.

${ }^{17}$ Zip code latitude and longitude are obtained from the U.S. Census Bureau's ZIP Code Tabulation Area (ZCTA) files, available at http://www.census.gov/geo/www/gazetteer/places2k.html. The distance (D) between two points, (longitude1, latitutde1) and (longitude2, latitutde2), on the earth is calculated using the

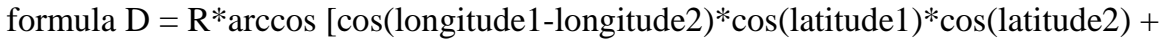
$\sin ($ latitude1)*sin(latitude2)], where $\mathrm{R}$ is the radius of the earth (3,961 miles). See the derivation of this formula at http://www.cs.cmu.edu/ mws/lld.html (accessed on April 23, 2006).
} 
entrepreneur. It is clear that the overwhelming majority of repeat entrepreneurs stay local when they move on to the next venture. In fact, more than three-quarters of them (76.3\%) move less than 50 miles away. ${ }^{18}$ This suggests that the majority of repeat entrepreneurs do not move far away to start their next ventures, which should allow them to access the same social network as before.

\subsection{Variables for regression analysis}

This study's version of the VentureOne data by design only covers VC deals completed in or after 1992. Although some firms founded before 1992 are captured by the database, they are not representative start-ups of their cohorts. In fact, many firms founded before 1992 in the VentureOne database are existing businesses that seek risk capital to support part of their operations or for a restart rather than brand-new start-ups. Therefore, I decided to exclude all firms founded before 1992 from the regression analysis. This section describes the variables used in the regression analysis (see Table 4 for a summary).

I focus on four dependent variables at the firm level: time to the first-round VC financing that is measured by months elapsed between the start-up's founding date and the closing date of the first-round VC, ${ }^{19}$ amount of VC raised in the first round, amount of VC raised in any round, and total amount of VC raised. The amount of VC is always measured in millions of 1996 dollars, converted using the GDP deflator.

Explanatory variables include four entrepreneur type dummies. These variables indicate whether a start-up is a repeat entrepreneur's first firm, subsequent firm, an experienced entrepreneur's firm, or a novice entrepreneur's firm. Firms founded by novice entrepreneurs serve as the reference group. To test hypotheses $1-3$, I am particularly interested in whether the other three dummy variables are significantly correlated with the dependent variables.

The following variables are used as controls:

\footnotetext{
${ }^{18}$ The data also show that 78.1\% (282/361) of repeat entrepreneurs stayed in the same state when they found their subsequent firms, 43.5\% (157/361) had the same telephone area code, and 12.7\% (46/361) stayed in the same zip code. Notice, I counted more than once those entrepreneurs who founded more than two firms. Thus there is a total of 361 pairs of consecutive firms founded by repeat entrepreneurs: $304+26$ $+(2 * 11)+(3 * 3)=361$.

19 This is not the "first" (earliest) round of venture capital a start-up completed. Rather, it is the round labeled as the "first round" by the round class variable. A small fraction of start-ups completed a "seed round" before the "first round."
} 
Firm age at VC round: This variable is measured by months elapsed between a firm's start date and a VC deal's closing date. Older firms tend to be larger and involved in more activities, and thus need more capital. In addition, the promise of an older firm is likely to be clearer to the investors. Given that venture capitalists still want to invest in it, it must be a good business that deserves more money. Thus one expects a positive relationship between start-up age and the amount of VC it raised. When the total amount of VC is used as the dependent variable, the relevant age control is firm age at the last VC round.

Total number of VC rounds completed: This variable is used as a control when I analyze the total amount of VC raised by a firm. Naturally, one expects a positive relationship between number of VC rounds and the total amount of VC raised.

Year dummies: The availability of VC changed a lot from one year to the next. Total VC investment in the United States (calculated using the VentureOne data) grew rapidly from $\$ 3.5$ billion in 1992 to $\$ 88.9$ billion in 2000, and sharply declined to $\$ 28.0$ billion in 2001 as the Internet bubble burst. Such year-to-year changes must have affected a start-up's access to VC. I use a start-up's start year dummy or the VC deal's closing year dummy, whichever is more appropriate for the analysis in hand, to control for the cohort effect.

Industry dummies: A total of 16 industry dummies are generated. Some industries are necessarily more capital intensive than others, and start-ups in such industries should receive more VC. Time to the first-round VC may also vary across industries.

High-tech center dummies: These are a set of dummy variables indicating whether a firm is located in one of the major high-tech centers in the U.S. (See the Appendix for the geographic definition of high-tech centers.) VC is more easily available in high-tech centers such as Silicon Valley and Boston, and start-ups in these regions are expected to have quicker access to VC and raise more money. Also, start-ups in high-tech centers may raise more VC based on need because operating costs are usually higher in such regions.

Round class dummies: For every start-up, the amount of VC raised in an early round of financing is likely to be less than in later rounds. For this reason, it is necessary to control for round class when a start-up's different VC rounds are included in a 
regression as separate observations. Four round class dummies were constructed to indicate seed round, first round, second round, and later round. The comparison group includes other VC rounds such as restart and venture leasing.

\section{Empirical Results}

This section presents regression results and examines whether they support hypotheses 1-3. For all regressions, I report standard errors robust to heteroskedasticity. ${ }^{20}$

\subsection{Entrepreneurial experience and the timing of VC funding}

I first examine the timing of a start-up’s first major VC deal and check whether serial entrepreneurs have quicker access to VC in their subsequent firm-founding activities.

Table 5 shows the average time to the first-round VC by entrepreneur type. On average, novice entrepreneurs wait 19.5 months to have the first-round VC in place; the average is 16.6 months for the first start-ups by repeat entrepreneurs and 19.2 months for start-ups by experienced entrepreneurs. One-tailed t-tests show that the difference between experienced entrepreneurs and novice entrepreneurs is not statistically significant ( $p$-value $=0.38$ ) and that the difference between repeat entrepreneurs when founding their first firms and novice entrepreneurs is only marginally significant (pvalue $=0.09$ ). But it takes much less time for repeat entrepreneurs to obtain capital for their subsequent firms. For the second and later start-ups founded by repeat entrepreneurs, the average waiting time to first-round VC is 9.0 months, statistically significantly lower than all the other averages at the $1 \%$ level in one-tailed t-tests. These seem to be consistent with Hypotheses $1 \mathrm{a}$ and $1 \mathrm{~b}$.

However, these differences in waiting time may simply reflect a cohort effect. The second and subsequent start-ups by repeat entrepreneurs, by definition, were founded later. And VC was more easily available in the late 1990s during the Internet boom, which might have made it easier for start-ups to secure VC investment quickly. So I run an OLS regression to control for cohort effect and other relevant factors.

\footnotetext{
${ }^{20}$ In one case, when different VC deals completed by a single VC-backed firm are treated as separate observations, I report standard errors that cluster on the firm.
} 
Results in Table 6 show that compared to start-ups founded by novice entrepreneurs, subsequent start-ups founded by repeat entrepreneurs have much quicker access to VC. On average, they are 9.5 months younger at the first-round VC financing, after controlling for confounding factors. This is consistent with hypothesis 1a. The first start-ups by repeat entrepreneurs and those founded by experienced entrepreneurs have no advantage in terms of the timing of the first-round VC. The coefficients of the firstfirm-repeat-entrepreneur dummy and the experienced-entrepreneur dummy are very small (-0.2 and -0.3, respectively) and not statistically different from zero. Since neither experienced entrepreneurs nor repeat entrepreneurs when founding their first firms have any venture-backed prior founding experience, these results support hypothesis $1 \mathrm{~b}$.

Venture-backed firms concentrate in high-tech industries, in which the fast pace of innovation gives the first mover a large advantage. As Zhang (2007) shows, quicker access to VC is correlated with a higher probability of completing an IPO, a better chance of making profit, and a larger employment size. Therefore, repeat entrepreneurs' quicker access to VC can have a substantial effect on the performance of their subsequent ventures.

\subsection{Entrepreneurial experience and the size of VC funding}

I next examine whether experienced start-up founders raise more VC than novice entrepreneurs. The regression results, using three different VC measures as dependent variables, are presented in Table 7.

Model (1) in Table 7 explains the amount of money raised in the first-round VC financing. It is expected that the asymmetric information problem is the most serious in this round because it is often the case that venture capitalists and the entrepreneur just started their relationship in the first round. Model (1) shows that compared with start-ups founded by novice entrepreneurs, subsequent firms founded by repeat entrepreneurs receive $\$ 4.1$ million more at the first round of financing. This difference is substantial given that the total amount of money raised in the first round on average is only $\$ 7.47$ million.

In contrast, repeat entrepreneurs' first firms did not raise more money at the first round. In other words, when repeat entrepreneurs themselves for the first time received some VC investment, they were just like other novice entrepreneurs at the first round. 
Similarly, experienced entrepreneurs do not raise more money for their start-ups at the first round, although they are expected to have acquired more skills from their prior founding experience.

These results from Model (1) support hypotheses 2a and 2b. They suggest that entrepreneurs with venture-backed prior founding experience raise more VC at an early stage of VC financing, but this advantage is entirely derived from the connections to VC investors that they previously established instead of from their enhanced entrepreneurial skills. In the previous section, I showed that subsequent firms founded by repeat entrepreneurs also have significantly quicker access to VC. Together, these results clearly show that entrepreneurs with venture-backed prior founding experience have a head start in the process of raising VC. However, entrepreneurs with non-VC-backed prior founding experience do not have any advantage at the very early stage of VC financing.

Because some start-ups completed a seed round before the first round, I tried a different specification using the sum of these two rounds of $\mathrm{VC}$ as the dependent variable. The results are qualitatively identical to those of Model (1). This is not surprising given that generally the size of a seed round is much smaller than the first round and thus adding the seed round VC to the first round yields essentially the same dependent variable.

Model (2) in Table 7 uses the size of any VC round as the dependent variable. That is, if a firm completed several rounds, every round is included in the regression as a separate observation. I added an additional set of dummy variables to control for round class since early rounds naturally have a smaller size than later rounds. Model (2) again shows that subsequent firms founded by repeat entrepreneurs receive more VC than novice entrepreneurs. The difference is $\$ 3.7$ million. This is actually smaller than the extra $\mathrm{VC}$ received by repeat entrepreneurs in the first round, suggesting that their advantage diminished in later rounds.

In contrast with the results from Model (1), the coefficient of firms founded by experienced entrepreneurs in Model (2) is also positive and statistically significant. On average, an experienced entrepreneur raises $\$ 0.8$ million more than a novice entrepreneur. This suggests that although at the first round of financing venture capitalists do not favor previous firm-founding experience that does not involve VC, those 
entrepreneurs do learn a great deal from that experience. Such acquired skills or knowledge may soon be recognized by venture capitalists and help experienced entrepreneurs raise more VC money in later rounds of financing. These results in Model (2) support hypotheses 3a and 3b.

Unlike the results of Model (1), in Model (2) the first firms founded by repeat entrepreneurs also raise more money. They raised $\$ 2.2$ million more, substantially larger than the extra amount of VC raised by experienced entrepreneurs. One possible explanation of this result is that repeat entrepreneurs are a special group of individuals whose qualities are particularly suitable for business creation. Although venture capitalists did not recognize this in the first round of financing when they invested in their first firms, they might soon learn about the superior qualities of those entrepreneurs based on observed performance. ${ }^{21}$ Consequently, venture capitalists might have invested more money in repeat entrepreneurs' first firms in later rounds of financing, which explains why repeat entrepreneurs raise more money even in their first experience with VC investors.

It is important to note that even repeat entrepreneurs themselves might not know at the very beginning that they have a comparative advantage in business creation. They might not recognize their own qualities until they raised a large amount of capital in the process of starting their first firms. And perhaps raising a lot of money for their first firms is exactly the reason why they decided to repeat the experience. In any case, this seems to be a result of self-selection that individuals choose to become repeat entrepreneurs partly because they raised more VC for their first firms. Unfortunately, the VentureOne data contain no information about the founder's individual characteristics that can be used to correct for this selection bias econometrically.

Unexpectedly, in Model (2), start-up age always has a negative and statistically significant coefficient. Most likely, this reflects the fact that older firms tend to complete their VC deals in the early 1990s when VC was much scarcer than in the late 1990s. The closing year dummies should have picked up some of this effect, but perhaps not all of it.

\footnotetext{
${ }^{21}$ Here we should not confuse the performance of the entrepreneur with the performance of the firm. Even a great entrepreneur may produce failures, because many other factors affect the performance of the firm. Such factors may include the overall economic trend, unanticipated demand, supply, or price shocks, and luck, which are all out of the entrepreneur's control. See Sarasvathy and Menon (2003) for an alternative and more sophisticated argument.
} 
Model (3) in Table 7 tests hypotheses 3a and 3b using an alternative specification, taking each firm as a single observation to examine the total amount of VC it raised over different rounds of financing. Results here are qualitatively similar to those of Model (2). Again, repeat entrepreneurs raise more money for their subsequent firms. The difference is \$5.7 million. But, as shown in Model (1), such firms receive \$4.1 million more in the first round of financing. The difference between these numbers again suggests that the advantage associated with venture-backed prior founding experience is most prominent in the first round. This makes sense because over time all entrepreneurs, including those without previously established ties to VC investors, would gradually overcome the asymmetric information problem between them and the venture capitalists. And therefore entrepreneurs without venture-backed prior founding experience should become less disadvantaged in later rounds of financing. The coefficient of the experiencedentrepreneur dummy is still positive and statistically significant, suggesting that skills learned from prior founding experience does help a start-up founder raise more VC money over a longer run. Again, these results support hypotheses 3a and 3b.

Model (3) shows that even the first firm founded by a repeat entrepreneur raises more VC in total. Assuming that there is self-selection and only the most capable entrepreneurs choose to become repeat entrepreneurs, then one can consider the coefficient of the first-firm-repeat-entrepreneur dummy as the extra VC money they command only because of their superior skill endowment before they founded their first firms. When they found the subsequent firms, they have more skills from prior experience and also have established connections, both of which help them raise more VC money. Thus it is reasonable to see that the coefficient of the subsequent-firm-repeatentrepreneur is bigger than that for first-firm-repeat-entrepreneur dummy (5.60 vs. 4.15). However, the difference between these two $(1.45=5.60-4.15)$ seems too small given that an experienced entrepreneur, with only the enhanced skills but not established ties, raise \$1.61 million more than novice entrepreneurs. This suggests that repeat entrepreneurs, when they found their subsequent firms, may need less VC than before, either because they become richer as successful entrepreneurs or because they become more reluctant to give up their ownership in exchange for equity investment. 
In Model (3), start-up age has a positive and statistically significant coefficient. That is, older firms raise a larger amount of VC than younger ones. The number of VC rounds also has a significant and positive coefficient. More VC rounds bring more money, which is not surprising.

\section{Conclusions and Discussion}

\subsection{Findings and contributions}

This paper examines whether entrepreneurs with prior founding experience have any advantage over novice entrepreneurs in the process of raising VC. I distinguished between venture- and non-venture-backed founding experiences and examined their effects on four measures: time to the first-round VC, the amount of VC raised in the first round, in any round, and the total amount of VC raised.

I find that entrepreneurs with venture-backed founding experience gain access to VC more quickly and raise more VC in the first round than novice entrepreneurs. This advantage at the early stage appears to be a result of their previously established connections to VC investors, because experienced entrepreneurs, also with prior founding experience but without connections to VC, do not have quicker access to VC and do not raise more VC in the first round than novice entrepreneurs. Repeat entrepreneurs' first firms, founded when they themselves had no connections with venture capitalists, do not have this advantage either, further confirming the importance of ties to VC investors at the very early stage of $\mathrm{VC}$ financing.

These results suggest that serial entrepreneurs who were previously venturebacked will go to the venture capitalists to whom they have direct or indirect ties, and those venture capitalists are willing to provide more early-stage capital to them based on trust, referrals, or other trusted information gathered through previous established connections. Indeed, this study shows that over three-quarters of repeat entrepreneurs' subsequent firms are located within 50 miles from their previous firms. In addition, it takes much less time for repeat entrepreneurs to complete the first-round VC financing for their subsequent start-ups. These results are both consistent with the conjecture that entrepreneurs with venture-backed founding experience exploit their connections with 
venture capitalists in the process of raising VC for their later start-ups and that such connections are indeed helpful.

When I also consider VC raised in later rounds, whether included as separate rounds or added to the total, experienced entrepreneurs, whose previous firms were not venture-backed, also appear to raise more VC than novice entrepreneurs. This suggests that entrepreneurs indeed learn from their previous experience and venture capitalists will recognize this over time and invest more money in them later on. Thus the skills these entrepreneurs acquired from earlier founding experience do benefit their later firms.

The findings summarized above constitute this paper's major contributions to the literature, which is two-fold. First, it helps scholars as well as practitioners better understand the importance of an entrepreneur's prior firm-founding experience. A large body of literature on experienced firm founders is motivated by the hypothesis that prior experience enhances entrepreneurial skills. This paper provides empirical evidence consistent with the hypothesis. What distinguishes this paper from most existing literature is that it also considers prior founding experience as a way of building up the entrepreneur's social capital that can help his later firms. Second, this paper helps scholars as well as practitioners better understand venture capitalists’ investment decision process. Existing literature suggests that venture capitalists will favor start-up founders with more entrepreneurial skills and with ties to the VC world. This paper's findings suggest that better skills and established connections are important at different stages of VC financing. At the very early stage, the entrepreneur's ties to the VC world are most advantageous; in later rounds, enhanced entrepreneurial skills become helpful too.

Out of the existing literature on entrepreneurial experience and serial entrepreneurs, two recent studies are most closely related to this one. Hsu (2007) uses survey data of 149 technology start-ups to investigate how the entrepreneur's human and social capital is related to VC funding and valuation. He finds that entrepreneurs with prior founding experience are more likely to receive funding through direct ties in the VC world and have a higher valuation of the start-up by the VC investors. My study here finds such experienced founders also have quicker access to VC and raise more VC, which is consistent with and complementary to Hsu's findings. 
In a recent working paper, Gompers et al. (2006) also use data from VentureOne to examine the importance of entrepreneurial skills. They find that successful entrepreneurs (defined as those whose previous firms went public) are more likely to succeed in subsequent ventures than novice entrepreneurs and entrepreneurs whose previous firms failed. In addition, they find that previously successful entrepreneurs do not benefit from value-added services of top-tier VC firms and that they do not extract higher financial returns from their successes. They note that later ventures of repeat entrepreneurs tend to receive first-round funding at a younger age, consistent with findings in this paper. They focus exclusively on the entrepreneurs who had multiple VCbacked firms (i.e., repeat entrepreneurs in my terminology) whereas I also examine the entrepreneurs with non-VC-backed experience. They study the performance and the valuation of firms founded by serial entrepreneurs whereas I investigate the performance of serial entrepreneurs in the process of raising VC. Therefore, Gompers et al. (2006) and this study are also highly complementary in the attempt to better understand serial entrepreneurs.

\subsection{Limitations and future research}

This study's regression analysis, when taking into account later rounds of VC financing, reveals that a repeat entrepreneur's first firm also receives more VC. This is a sign of self-selection that high-ability entrepreneurs are more likely to become serial entrepreneurs. Although the technique for correcting this kind of selection biases has become standard (Heckman, 1979), it is impossible to implement here because the VentureOne founder data provide no information about an entrepreneur's individual characteristics. This inability to overcome the problem of self-selection is the primary limitation of this study.

Another limitation of the paper is related to the practice of using entrepreneurs' prior venture-backed founding experience to proxy their ties to venture capitalists. Given that VC investment tends to be local and that most repeat entrepreneurs do not move far away from their previous firms when they found their next firms, this proxy should be a good one. However, the nature of the ties between repeat entrepreneurs and venture capitalists remains unclear as does the channel through which those ties become useful. For example, we do not know whether repeat entrepreneurs directly go back to their 
previous investors to raise $\mathrm{VC}$ or find new ones through their connections in the VC world.

Given these limitations of the paper, the results as summarized above should be taken as suggestive rather than conclusive, calling for further investigation along this line. Future work on the following topics will likely be fruitful.

First, it is highly desirable to control for self-selection biases and conduct a cleaner test of hypothesis 3a. More specifically, one wants to study to what extent the observed extra VC raised by repeat entrepreneurs can be explained by the fact that only particular types of entrepreneurs choose to become repeat entrepreneurs. To answer this question, one needs a database that contains a wide range of individual characteristics for both serial and novice entrepreneurs.

Second, it is necessary to directly examine whether serial entrepreneurs go back to the venture capitalists they know to seek support in their subsequent ventures and whether that is the key factor that explains why they have quicker access to a larger amount of VC. A crucial assumption I used to motivate this study and explain some of the findings is that repeat entrepreneurs exploit their previously established connections to the VC world in the process of raising $\mathrm{VC}$ for their subsequent ventures. It is important to check whether this assumption resembles reality. In fact, VentureOne does collect data about the major investors involved in each round of VC financing, although I do not have access to such information. Thus a more complete version of the VentureOne data can be used to answer this question.

Third, it is useful to investigate how the advantage of serial entrepreneurs in the process of raising VC contributes to their subsequent successes. Zhang (2007) shows that early access to a large amount of VC gives a start-up an edge in fast-paced technology industries, which leads to better performance later on in terms of profitability, employment growth, and completing an IPO. This implies that the advantage of serial entrepreneurs over the lifetime of their subsequent ventures may be even more significant than is shown in this study. 


\section{Appendix: Geographic Definition of High-Tech Centers}

Following Saxenian (1999), I define Silicon Valley as the whole Santa Clara County and adjacent cities in Alameda, San Mateo, and Santa Cruz Counties.

\begin{tabular}{ll}
\hline City & Zip Code \\
\hline $\begin{array}{l}\text { Santa Clara County } \\
\text { All }\end{array}$ & All \\
& \\
Alameda County & $94536-39,94555$ \\
Fremont & 94560 \\
Newark & 94587 \\
Union City & \\
& \\
San Mateo County & 94027 \\
Atherton & 94002 \\
Belmont & 94303 \\
East Palo Alto & 94404 \\
Foster City & 94025 \\
Menlo Park & $94061-65$ \\
Redwood City & 94070 \\
San Carlos & $94400-03$ \\
San Mateo & \\
Santa Cruz County & $95066-67$ \\
Scotts Valley & \\
\hline
\end{tabular}

Other regions are defined using telephone area codes.

\begin{tabular}{ll}
\hline Region & Area Code \\
\hline San Francisco Bay Area & $\begin{array}{l}\text { Silicon Valley, plus 408, 415, 510, 650, } 925 \text { if not already } \\
\text { in Silicon Valley }\end{array}$ \\
Boston & 508, 617, 781, 978 \\
New York & 201, 212, 347, 516, 646, 718, 732, 845, 908, 914, 917, 973 \\
Seattle & 206, 253, 360, 425 \\
Washington, D.C. & 202, 240, 301, 571, 703 \\
\hline
\end{tabular}




\section{References}

Amit, Raphael, Lawrence Glosten, and Eitan Muller (1990). "Entrepreneurial Ability, Venture Investments, and Risk Sharing,” Management Science 38, 1232-1245.

Batjargal, Bat and Mannie M. Liu (2004). “Entrepreneurs' Access to Private Equity in China: The Role of Social Capital,” Organization Science 15, 159-172.

Birley, Sue (1985). “The Role of Networks in the Entrepreneurial Process,” Journal of Business Venturing 1, 107-117.

Birley, Sue and Paul Westhead (1994). "A Comparison of New Businesses Established by 'Novice' and 'Habitual' Founders in Great Britain,” International Small Business Journal 12, 38-60.

Bruno, Albert V. and Tyzoon T. Tyebjee (1983). "The One That Got away: A Study of Ventures Rejected by Venture Capitalists,” in John A. Hornaday, Jeffry A. Timmons, and Karl H. Vesper (eds.), Frontiers of Entrepreneurship Research, Babson College, Wellesley, MA, 289-306.

Bruno, Albert V. and Tyzoon T. Tyebjee (1986). “The Destinies of Rejected Venture Capital Deals,” Sloan Management Review 27, 43-53.

Burt, Ronald S. (1997). “The Contingent Value of Social Capital,” Administrative Science Quarterly 42, 339-365.

Bygrave, William D. and Jeffrey A. Timmons (1992). Venture Capital at the Crossroads, Boston, MA: Harvard Business School Press.

Carland, JoAnn C., James W. Carland, and Wayne H. Stewart Jr. (2000). “The Indefatigable Entrepreneur: A Study of the Dispositions of Multiple Venture Founders," Journal of Business and Entrepreneurship 12, 1-18.

Carter, Sara and Monder Ram (2003). “Reassessing Portfolio Entrepreneurship,” Small Business Economics 21, 371-380.

Chambers, Brian R., Stuart L. Hart and Daniel R. Denison (1988). "Founding Team Experience and New Firm Performance,” in B. Kirchhoff, W. Long, E. McMullan, K. Vesper and W. Wetzel (eds.) Frontiers of Entrepreneurship Research. Babson College. Cochrane, John H. (2005). “The Risk and Return of Venture Capital," Journal of Financial Economics 75, 3-52.

Cooke, Philip and David Wills (1999). "Small Firms, Social Capital and the Enhancement of Business Performance through Innovation Programmes,” Small Business Economics 13, 219-234.

Davidsson, Per and Benson Honig (2003). "The Role of Social and Human Capital among Nascent Entrepreneurs,” Journal of Business Venturing 18, 301-331.

Donkels, R., B. Dupont and P. Michel (1987). "Multiple Business Starters. Who? Why? What?” Journal of Small Business and Entrepreneurship 5: 48-63.

Elfring, Tom and Willem Hulsink (2003). "Networks in Entrepreneurship: The Case of High-technology Firms,” Small Business Economics 21, 409-422.

Florin, Juan, Mickael Lubatkin, and Willaim Schulze (2003). “A Social Capital Model of High-Growth Ventures,” Academy of Management Journal 46, 374-384. 
Franke, Nikolaus, Marc Gruber, Dietmar Harhoff, and Joachim Henkel (2007). "Venture Capitalists’ Evaluations of Start-up Teams: Trade-offs, Knock-out Criteria, and the Impact of VC Experience,” Entrepreneurship Theory and Practice, forthcoming.

Fried, Vance H. and Robert D. Hisrich (1994). "Toward a Model of Venture Capital Investment Decision Making,” Financial Management, 23: 28-37.

Gompers, Paul A. (1995). "Optimal Investment, Monitoring, and the Staging of Venture Capital,” Journal of Finance 50, 1461-1489.

Gompers, Paul and Josh Lerner (1999). The Venture Capital Cycle, Cambridge, MA: MIT Press.

Gompers, Paul and Josh Lerner (2000). "Money Chasing Deals? The Impact of Fund Inflows on Private Equity Valuations,” Journal of Financial Economics 55, 281-325.

Gompers, Paul, Josh Lerner, and David Scharfstein (2005). "Entrepreneurial Spawning: Public Corporations and the Genesis of New Ventures, 1986-1999,” Journal of Finance 60, 577-614.

Gompers, Paul A., Anna Kovner, Josh Lerner, and David Scharfstein (2006). "Skill vs. Luck in Entrepreneurship and Venture Capital: Evidence from Serial Entrepreneurs," NBER Working Paper No. 12592.

Granovetter Mark (1985). "Economic Action and Social Structure: The Problem of Embeddedness,” American Journal of Sociology 91, 481-510.

Hansen, Eric L. (1995). “Entrepreneurial Networks and New Organization Growth,” Entrepreneurship Theory and Practice 19, 7-29.

Heckman, James J. (1979). "Sample Selection Bias as a Specification Error,” Econometrica 47, 153-161.

Hellmann, Thomas F. (2000), "Venture Capitalists: The Coaches of Silicon Valley," in Lee, Chong-Moon, William F. Miller, Marguerite Gong Hancock, and Henry S. Rowen (eds.), The Silicon Valley Edge: A Habitat for Innovation and Entrepreneurship, Stanford: Stanford University Press, 276-294.

Hisrich, Robert D. and A. D. Jankowitz (1990). "Intuition in Venture Capital Decisions: An Exploratory Study Using a New Technique,” Journal of Business Venturing 5, 49-62. Hsu, David H. (2007). "Experienced Entrepreneurial Founders and Venture Capital Funding,” Research Policy 36, 722-741.

Hutt, R. W. and B. Thomas (1985). "Venture Capital in Arizona,” Frontiers of Entrepreneurship Research, 155-169.

Jenssen, Jan Inge (2001). “Social Networks, Resources and Entrepreneurship,” The International Journal of Entrepreneurship and Innovation 2, 103-109.

Jenssen, Jan Inge and Harold F. Koenig (2002). “The Effect of Social Networks on Resource Access and Business Start-ups,” European Planning Studies 10, 1039-1046.

Kaplan, Steven and Per Strömberg (2001). "Venture Capitalists as Principals: Contracting, Screening, and Monitoring,” American Economic Review 91, 426-430.

Kaplan, Steven and Per Strömberg (2003). "Financial Contracting Theory Meets the Real World: Evidence from Venture Capital Contracts,” Review of Economic Studies 70, 281316. 
Kaplan, Steven and Per Strömberg (2004). "Contracts, Characteristics, and Actions: Evidence from Venture Capitalist Analyses,” Journal of Finance 59, 2177-2210.

Kaplan, Steven, Berk Sensoy, and Per Strömberg (2002). “How Well Do Venture Capital Databases Reflect Actual Investments?” manuscript, University of Chicago.

Kolvereid, L. and E. Bullvag (1993). “Novices Versus Experienced Founders: An exporatory Investigation.” In S. Birley and I. MacMillian (eds.) Entrepreneurship Research: Global Perspectives, pp. 275-285. Elsevier Science Publishers, Amsterdam. Lazear, Edward (2004). “Balanced Skills and Entrepreneurship,” American Economic Review Papers and Proceedings, 94(2), 208-211.

Lazear, Edward (2005). “Entrepreneurship,” Journal of Labor Economics 23, 649-680.

Leland, Hayne E. and David H. Pyle (1977). "Informational Asymmetries, Financial Structure, and Financial Intermediation,” Journal of Finance 32, 371-387.

MacMillan, Ian C. (1986). “To really learn about entrepreneurship, let's study habitual entrepreneurs,” Journal of Business Venturing 1, 241-243.

MacMillan, Ian C., Robin Siegel, and P.N. SubbaNarasimha (1985). "Criteria Used by Venture Capitalists to Evaluate New Venture Proposals,” Journal of Business Venturing 1, 119-128.

MacMillan, Ian C., Lauriann Zemann, and P.N. SubbaNarasimha (1987). “Criteria Distinguishing Successful from Unsuccessful Ventures in the Venture Screening Process,” Journal of Business Venturing 2, 123-137.

Muzyka, Dan, Sue Birley, and Benoit Leleux (1996). "Trade-offs in the Investment Decisions of European VCs,” Journal of Business Venturing 11, 273-288.

Podolny, Joel M. (1994). "Market Uncertainty and the Social Character of Economic Exchange,” Administrative Science Quarterly 39, 458-483.

Riquelme, Hernan and Tudor Rickards (1992). "Hybrid Conjoint Analysis: An Estimation Probe in New Venture Decisions,” Journal of Business Venturing 7, 505-518.

Rosa, Peter (1998). "Entrepreneurial Processes of Business Cluster Formation and Growth by 'Habitual' Entrepreneurs,” Entrepreneurship Theory and Practice 22, 43-61.

Sandberg, William R., David M. Schweiger, and Charles W. Hofer (1988). "Use of Verbal Protocols in Determining Venture Capitalists’ Decision Process,” Entrepreneurship Theory and Practice 13, 182-196.

Sarasvathy, Saras D. and Anil R. Menon (2003). "Failing Firms and Successful Entrepreneurs: Serial Entrepreneurship as a Temporal Portfolio.” Darden Business School Working Paper No. 04-05.

Saxenian, AnnaLee (1999). Silicon Valley's New Immigrant Entrepreneurs, Public Policy Institute of California, San Francisco, CA.

Schaper, Michael, Gary Mankelow, and Brian Gibson (2005). "Serial Entrepreneurship: An Exploratory Analysis of Australian Firms," paper presented at the $50^{\text {th }}$ International Council for Small Business (ICSB) World Conference.

Scott, Michael and Peter Rosa (1996). "Has Firm Level Analysis Reached Its Limits? Time for a Rethink,” International Small Business Journal 14, 81-89. 
Shane, Scott and Daniel Cable (2002). "Network Ties, Reputation, and the Financing of New Ventures," Management Science 48, 364-381.

Shepherd, Dean A. and Andrew Zacharakis (1999). "Conjoint Analysis: A New Methodology for Researching the Decision Policies of Venture Capitalists," Venture Capital 1, 197-217.

Sorenson, Olav and Toby E. Stuart (2001). "Syndication Networks and the Spatial Distribution of Venture Capital Investments,” American Journal of Sociology 106, 15461586.

Starr, Jennifer A. and William D. Bygrave (1991). "The Assets and Liabilities of Prior Start-up Experience: An Exploratory Study of Multiple Venture Entrepreneurs.” In Churchill, N. C., W. D. Bygrave, J. G. Covin, D. L. Sexton, D. P. Slevin, K. H. Vesper, and W. E. Wetzel (eds), Frontiers of Entrepreneurship Research. Wellesley, MA: Babson College, pp. 213-227.

Tyebjee, Tyzoon T. and Albert V. Bruno (1981). "Venture Capital Decision Making: Preliminary Results from Three Empirical Studies,” Frontiers of Entrepreneurship Research, 316-334.

Tyebjee, Tyzoon T. and Albert V. Bruno (1984). "A Model of Venture Capitalist Investment Activity,” Management Science 30, 1051-1066.

Ucbasaran, Deniz, Mike Wright and Paul Westhead (2003). "A Longitudinal Study of Habitual Entrepreneurs: Starters and Acquirers," Entrepreneurship and Regional Development 15, 207-228.

Uzzi, Brian (1996). "The Sources and Consequences of Embeddedness for the Economic Performance of Organizations: The Network Effect," American Sociological Review 61, 674-698.

Uzzi, Brian (1999). "Embeddedness in the Making of Financial Capital: How Social Relations and Networks Benefit Firms Seeking Financing,” American Sociological Review 64, 481-505.

VentureOne Corporation (2000). The VentureOne Venture Capital Sourcebook, San Francisco, CA.

VentureOne Corporation (2001). Venture Capital Industry Report, San Francisco, CA.

Westhead, Paul and Mike Wright (1998a). "Novice, Portfolio, and Serial Founders: Are They Different?” Journal of Business Venturing 13, 173-204.

Westhead, Paul and Mike Wright (1998b). "Novice, Portfolio, and Serial Founders in Rural and Urban Areas," Entrepreneurship Theory and Practice 22, 63-100.

Westhead, Paul, Deniz Ucbasaran, and Mike Wright (2005a). "Experience and Cognition: Do Novice, Serial and Portfolio Entrepreneurs Differ?” International Small Business Journal 23, 72-98.

Westhead, Paul, Deniz Ucbasaran, and Mike Wright (2005b). "Decisions, Actions, and Performance: Do Novice, Serial, and Portfolio Entrepreneurs Differ?” Journal of Small Business Management 43, 393-417. 
Westhead, Paul, Deniz Ucbasaran, Mike Wright, and Martin Binks (2005c). "Novice, Serial and Portfolio Entrepreneur Behaviour and Contributions,” Small Business

Economics 25, 109-132.

Wright, Mike, Ken Robbie, and Chritine Ennew (1997a). "Venture Capitalists and Serial Entrepreneurs,” Journal of Business Venturing 12, 227-249.

Wright, Mike, Ken Robbie, and Chritine Ennew (1997b). “Serial Entrepreneurs,” British Journal of Management 8, 251-268.

Wright Mike, Paul Westhead, and Jeff Shol (1998). “Editors’ Introduction: Habitual Entrepreneurs and Angel Investors,” Entrepreneurship Theory and Practice 22, 5-21.

Yli-Renko, Helena, Erkko Autio, and Harry J. Sapienza (2001). “Social Capital, Knowledge Acquisition, and Knowledge Exploitation in Young Technology-Based Firms,” Strategic Management Journal 22, 587-613.

Zhang, Junfu (2006). “A Study of Academic Entrepreneurs Using Venture Capital Data,” Working Paper No. 2006.01, Public Policy Institute of California, San Francisco.

Zhang, Junfu (2007). “Access to Venture Capital and the Performance of VentureBacked Start-Ups in Silicon Valley”, Economic Development Quarterly 21(2), 124-147.

Zook, Matthew A. (2005). The Geography of the Internet Industry: Venture Capital, Dotcoms, and Local Knowledge, Malden, MA: Blackwell Publishing. 
Table 1: Classification of Venture-Backed Entrepreneurs

\begin{tabular}{|c|c|c|c|}
\hline Entrepreneur Type & Definition & $\begin{array}{l}\text { No. of } \\
\text { Individuals }\end{array}$ & $\begin{array}{l}\text { No. of Firms } \\
\text { Founded }\end{array}$ \\
\hline Serial entrepreneur & & 2,867 & 2,578 \\
\hline $\begin{array}{l}\text { Repeat } \\
\text { entrepreneur }\end{array}$ & $\begin{array}{l}\text { Has founded at least two firms in the } \\
\text { VentureOne database }\end{array}$ & 304 & 599 \\
\hline $\begin{array}{l}\text { Experienced } \\
\text { entrepreneur }\end{array}$ & $\begin{array}{l}\text { Has founded only one firm in the } \\
\text { VentureOne database but bio shows } \\
\text { previous founding experience }\end{array}$ & 2,563 & 1,979 \\
\hline Novice entrepreneur & $\begin{array}{l}\text { Has founded only one firm in the } \\
\text { VentureOne database and bio shows no } \\
\text { previous founding experience }\end{array}$ & 7,663 & 3,394 \\
\hline
\end{tabular}

Calculations in this Table are based on the full sample. 
Table 2: Industry Distribution of Venture-Backed Firms, by Entrepreneur Type

\begin{tabular}{|c|c|c|c|c|c|c|}
\hline Industry & $\begin{array}{l}\text { Firms by } \\
\text { Novice } \\
\text { Entrepreneurs }\end{array}$ & $\begin{array}{l}\% \text { of } \\
\text { total }\end{array}$ & $\begin{array}{c}\text { Firms by } \\
\text { Repeat } \\
\text { Entrepreneurs }\end{array}$ & $\begin{array}{l}\% \text { of } \\
\text { total }\end{array}$ & $\begin{array}{c}\text { Firms by } \\
\text { Experienced } \\
\text { Entrepreneurs }\end{array}$ & $\begin{array}{l}\% \text { of } \\
\text { total }\end{array}$ \\
\hline Adv/Spec Material & 14 & 0.41 & 4 & 0.67 & 8 & 0.40 \\
\hline Agriculture & 5 & 0.15 & 0 & 0 & 0 & 0 \\
\hline Biopharmaceutical & 215 & 6.33 & 53 & 8.85 & 83 & 4.19 \\
\hline Communication & 427 & 12.58 & 114 & 19.03 & 230 & 11.62 \\
\hline Consumer/Bus Prod & 32 & 0.94 & 0 & 0 & 20 & 1.01 \\
\hline Consumer/Bus Serv & 733 & 21.60 & 102 & 17.03 & 517 & 26.12 \\
\hline Electronics & 97 & 2.86 & 16 & 2.67 & 57 & 2.88 \\
\hline Energy & 6 & 0.18 & 0 & 0 & 2 & 0.10 \\
\hline Healthcare & 57 & 1.68 & 9 & 1.50 & 28 & 1.41 \\
\hline Information Services & 364 & 10.72 & 72 & 12.02 & 223 & 11.27 \\
\hline Medical Devices & 126 & 3.71 & 58 & 9.68 & 58 & 2.93 \\
\hline Medical Information & 108 & 3.18 & 11 & 1.84 & 60 & 3.03 \\
\hline Retailing & 92 & 2.71 & 15 & 2.50 & 47 & 2.37 \\
\hline Semiconductor & 159 & 4.68 & 19 & 3.17 & 69 & 3.49 \\
\hline Software & 954 & 28.11 & 125 & 20.87 & 574 & 29.00 \\
\hline Other & 5 & 0.15 & 1 & 0.17 & 3 & 0.15 \\
\hline Total & 3,394 & 100 & 599 & 100 & 1,979 & 100 \\
\hline
\end{tabular}

Calculations in this Table are based on the full sample. 
Table 3: Geographic Distribution of Venture-Backed Firms, by Entrepreneur Type

\begin{tabular}{|c|c|c|c|c|c|c|}
\hline State & $\begin{array}{c}\text { Firms by } \\
\text { Novice } \\
\text { Entrepreneurs }\end{array}$ & $\%$ of total & $\begin{array}{c}\text { Firms by } \\
\text { Repeat } \\
\text { Entrepreneurs }\end{array}$ & $\begin{array}{l}\% \text { of } \\
\text { total }\end{array}$ & $\begin{array}{c}\text { Firms by } \\
\text { Experienced } \\
\text { Entrepreneurs }\end{array}$ & $\%$ of total \\
\hline California & 1,408 & 41.48 & 348 & 58.10 & 877 & 44.32 \\
\hline Massachusetts & 358 & 10.55 & 81 & 13.52 & 221 & 11.17 \\
\hline New York & 216 & 6.36 & 25 & 4.17 & 124 & 6.27 \\
\hline Texas & 185 & 5.45 & 36 & 6.01 & 88 & 4.45 \\
\hline Washington & 119 & 3.51 & 20 & 3.34 & 81 & 4.09 \\
\hline Virginia & 112 & 3.30 & 7 & 1.17 & 68 & 3.44 \\
\hline Georgia & 98 & 2.89 & 4 & 0.67 & 43 & 2.17 \\
\hline Pennsylvania & 94 & 2.77 & 5 & 0.83 & 53 & 2.68 \\
\hline Colorado & 91 & 2.68 & 4 & 0.67 & 45 & 2.27 \\
\hline North Carolina & 82 & 2.42 & 9 & 1.50 & 40 & 2.02 \\
\hline New Jersey & 78 & 2.30 & 6 & 1.00 & 27 & 1.36 \\
\hline Illinois & 72 & 2.12 & 5 & 0.83 & 47 & 2.37 \\
\hline Maryland & 66 & 1.94 & 7 & 1.17 & 28 & 1.41 \\
\hline Florida & 60 & 1.77 & 6 & 1.00 & 36 & 1.82 \\
\hline Minnesota & 52 & 1.53 & 7 & 1.17 & 23 & 1.16 \\
\hline All other states & 303 & 8.93 & 29 & 4.84 & 134 & 8.99 \\
\hline Total & 3,394 & 100 & 599 & 100 & 1,979 & 100 \\
\hline
\end{tabular}

Calculations in this Table are based on the full sample. 
Table 4: Variable Definitions and Summary Statistics

\begin{tabular}{|c|c|c|c|}
\hline Variable & Definition & Mean & S.D. \\
\hline \multicolumn{4}{|l|}{ Dependent variables } \\
\hline Time to first-round VC & Months between a start-up’s founding date and closing date of its first-round VC & 18.43 & 19.22 \\
\hline Size of first-round VC & Amount of money (in millions of 1996 dollars) raised in the first-round VC financing & 7.47 & 10.45 \\
\hline Size of any round of VC & Amount of money (in millions of 1996 dollars) raised in any round of VC financing & 10.31 & 14.80 \\
\hline Total VC raised & Total amount of money (in millions of 1996 dollars) raised in all rounds of VC financing & 16.31 & 25.12 \\
\hline \multicolumn{4}{|c|}{ ( } \\
\hline First firm founded by a repeat entrepreneur & Dummy $=1$ if the firm is the first one founded by a repeat entrepreneur & 0.03 & 0.17 \\
\hline $\begin{array}{l}\text { Subsequent firm founded by a repeat } \\
\text { entrepreneur }\end{array}$ & Dummy $=1$ if the firm is the second or later one founded by a repeat entrepreneur & 0.06 & 0.24 \\
\hline Firm founded by an experienced entrepreneur & Dummy $=1$ if the firm is founded by an experienced entrepreneur & 0.26 & 0.44 \\
\hline Firm founded by a novice entrepreneur & Dummy $=1$ if the firm is founded by a novice entrepreneur, always excluded as reference group & 0.65 & 0.48 \\
\hline \multicolumn{4}{|l|}{ Control variables } \\
\hline Firm age at VC round & Months between start-up founding date and VC closing date & 25.98 & 21.71 \\
\hline Firm age at last VC round & Months between start-up founding date and closing date of the last round of VC financing & 26.97 & 22.86 \\
\hline Number of VC rounds completed & Total number of rounds of VC complete by the firm & 1.64 & 1.08 \\
\hline Firm start year dummies & Set of 10 dummies indicating a firm’s start year, 1992-2001 & ----- & ----- \\
\hline VC deal closing year dummies & Set of 10 dummies indicating the closing year of a VC round, 1992-2001 & ----- & ----- \\
\hline VC round class dummies & Set of 5 dummies indicating the stage of the VC round (seed, first, second, later, and other) & ----- & ----- \\
\hline Industry dummies & Set of 16 dummies indicating a firm’s industry (see list in Table 2) & ----- & ----- \\
\hline High-tech center dummies & $\begin{array}{l}\text { Set of } 6 \text { dummies indicating whether a firm is located in a VC-rich high-tech center (see list in } \\
\text { Appendix) }\end{array}$ & ----- & ----- \\
\hline
\end{tabular}

All start-ups in this sample were founded in or after 1992. 
Table 5: Time to First-Round Venture Capital, by Entrepreneur Type

\begin{tabular}{lcc}
\hline Start-up Category & $\begin{array}{c}\text { Time to First-Round VC, Months } \\
\text { (Std. Dev. in parenthesis) }\end{array}$ & No. of Observations \\
\hline $\begin{array}{l}\text { Start-ups founded by } \\
\text { novice entrepreneurs }\end{array}$ & 19.46 & 2,078 \\
& $(19.85)$ & \\
$\begin{array}{l}\text { First start-ups founded by } \\
\text { repeat entrepreneurs }\end{array}$ & 16.57 & 88 \\
& $(15.32)$ & 180 \\
$\begin{array}{l}\text { Later start-ups founded by } \\
\text { repeat entrepreneurs }\end{array}$ & 9.04 & 870 \\
$\begin{array}{l}\text { Start-ups founded by } \\
\text { experienced entrepreneurs }\end{array}$ & $(8.67)$ & \\
\hline
\end{tabular}

All start-ups in this sample were founded in or after 1992. 
Table 6: Timing of a Firm's First-Round Venture Capital

\begin{tabular}{lc}
\hline & OLS \\
& $\begin{array}{c}\text { Dependent Variable: } \\
\text { Months between founding } \\
\text { date and first-round VC } \\
\text { closing date }\end{array}$ \\
\hline Constant & $19.926^{* *}$ \\
& $(8.724)$ \\
First firm founded by a repeat entrepreneur & -0.195 \\
Subsequent firm founded by a repeat entrepreneur & $(2.062)$ \\
& $-9.463^{* * *}$ \\
Firm founded by an experienced entrepreneur & $(1.461)$ \\
& -0.317 \\
VC deal closing year dummies & $(0.751)$ \\
Industry dummies & Yes \\
High-tech center dummies & Yes \\
$\mathrm{R}^{2}$ & Yes \\
No. of observations & 0.075 \\
\hline
\end{tabular}

All start-ups in this sample were founded in or after 1992.

Heteroskedasticity robust standard errors are in parentheses.

$* * *, * *$, and $*$ denote statistical significance at the 1 per cent, 5 per cent, and 10 percent levels respectively.

Yes - Dummy variables are included as controls. 
Table 7: Venture Capital Raised

\begin{tabular}{|c|c|c|c|}
\hline Independent Variables & $\begin{array}{c}(1) \\
\text { Dependent Variable: Size } \\
\text { of first-round VC }\end{array}$ & $\begin{array}{l}\text { (2) } \\
\text { Dependent Variable: Size } \\
\text { of any round of VC }\end{array}$ & $\begin{array}{c}(3) \\
\text { Dependent Variable: } \\
\text { Total VC raised }\end{array}$ \\
\hline Constant & $\begin{array}{c}2.259 \\
(1.785)\end{array}$ & $\begin{array}{c}1.832 \\
(2.395)\end{array}$ & $\begin{array}{c}-23.510^{* * *} \\
(3.303)\end{array}$ \\
\hline First firm founded by a repeat entrepreneur & $\begin{array}{c}0.708 \\
(0.652)\end{array}$ & $\begin{array}{l}2.184 * * \\
(1.048)\end{array}$ & $\begin{array}{l}4.154^{*} \\
(2.390)\end{array}$ \\
\hline Subsequent firm founded by a repeat entrepreneur & $\begin{array}{c}4.064 * * * \\
(1.354)\end{array}$ & $\begin{array}{c}3.657 * * * \\
(1.118)\end{array}$ & $\begin{array}{c}5.605^{* * *} \\
(1.752)\end{array}$ \\
\hline Firm founded by an experienced entrepreneur & $\begin{array}{c}0.027 \\
(0.352)\end{array}$ & $\begin{array}{l}0.760^{*} \\
(0.446)\end{array}$ & $\begin{array}{l}1.608 * * \\
(0.775)\end{array}$ \\
\hline Firm age at VC round & $\begin{array}{l}0.015^{*} \\
(0.009)\end{array}$ & $\begin{array}{c}-0.038 * * * \\
(0.010)\end{array}$ & \\
\hline Firm age at last VC round & & & $\begin{array}{c}0.137 * * * \\
(0.018)\end{array}$ \\
\hline Number of VC rounds completed & & & $\begin{array}{l}11.155^{* * * *} \\
(0.555)\end{array}$ \\
\hline Firm start year dummies & & & Yes \\
\hline VC deal closing year dummies & Yes & Yes & \\
\hline VC round class dummies & & Yes & \\
\hline Industry dummies & Yes & Yes & Yes \\
\hline High-tech center dummies & Yes & Yes & Yes \\
\hline $\mathrm{R}^{2}$ & 0.098 & 0.201 & 0.309 \\
\hline No. of observations & 3,410 & 7,547 & 4,734 \\
\hline
\end{tabular}

All financial variables are measured in millions of 1996 dollars. All start-ups in the sample were founded in or after 1992.

For Models (1) and (3), heteroskedasticity robust standard errors are in parentheses. For Model (2), robust standard errors are computed by clustering at the VC-backed firm.

***, **, and * denote statistical significance at the 1 per cent, 5 per cent, and 10 percent levels respectively.

Yes - Dummy variables are included as controls. 
Figure 1: Histogram of Distance between a Repeat Entrepreneur's Two Consecutive Start-Ups

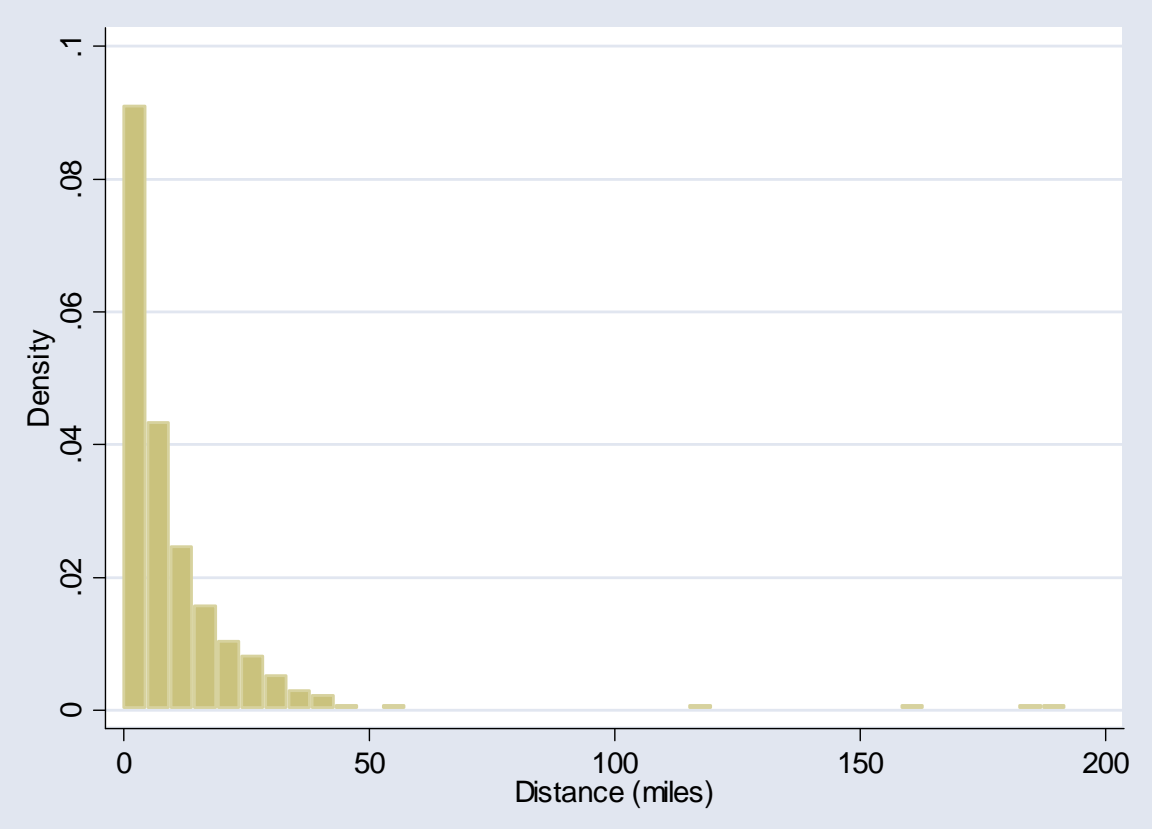

Note: The density is very low and almost always zero beyond 200 miles, which is omitted from this figure in order to have a zoomed-in view of the distribution. 